\title{
The world's best system of compensating injury?
}

\author{
RICHARD SMITH
}

One of the unique things about New Zealand, along with flightless birds and an absence of poisonous creatures, is its nofault scheme for compensating accidental injury. Since 1974 anybody injured in an accident has had no need to take legal action: he or she is compensated by the Accident Compensation Corporation (previously Commission), a statutory body. About 130000 claims a year are dealt with by the Accident Compensation Corporation (in a country of three million people) and it is, indeed, impossible to bring a common law action for personal injury.

Problems persist with the scheme (particularly over defining what is an accident and what is not), but it works, and most New Zealanders are convinced that it will continue; nobody will put the clock back. Lawyers, insurers, social reformers, academics, and journalists journey from all over the world to look at the scheme; members of the British Royal Commission on Civil Liability and Compensation for Personal Injury (the Pearson Commission) went there in September 1975.' (This was too early, I was told, both because little experience had been generated and because the new commissioners were anxious that the new scheme should be seen only in the best light.) The Pearson Commission reported on British problems in 1978, but most of its proposals remain on the drawing board. ${ }^{2}$ The problems, however, persist.

I recently joined the flow of journalists to New Zealand to look at the Accident Compensation Corporation scheme. I wanted primarily to look at the New Zealand way of compensating drug injury, but I took the opportunity to look also at the general working of the scheme and the particular problems of compensating for medical misadventure. This first article will

British Medical Journal, London WC1H 9JR RICHARD SMITH, MB, BSC, assistant editor describe the whole scheme, a second article will consider the problems with the scheme, and a third article will look at the particular problems of compensation for drug injury and medical misadventure.

My information comes from the many members of the Accident Compensation Corporation whom I met; from independent lawyers; doctors, and academics; and from books, articles, and reports. In addition to the government reports I have found three books particularly useful: Compensation for Inequality: a Study of Law and Social Change in New Zealand and Australia ${ }^{3}$ by Geoffrey Palmer, a former professor of law at Victoria University in Wellington, and now a New Zealand member of Parliament; Accident Compensation ${ }^{4}$ by Terence G Ison, a Canadian professor of law who spent three months in New Zealand studying the scheme; and Accident Compensation Coverage $^{5}$ by J L Fahy, who is now the managing director of the Accident Compensation Corporation.

\section{The emergence of a bold scheme}

Before 1974 New Zealand had a ragged and disjointed system of dealing with the injured-one similar to that existing in Britain now. Hospital treatment was free; general practitioner treatment was largely free; modest social security payments were available to some of the injured; there was a no-fault compensation scheme for those injured at work and for those incapacitated by industrial disease; and, apart from these provisions, the only other route to compensation was through the courts, and it was necessary to prove fault on somebody's part.

In September 1966 a three-man royal commission, chaired by Arthur Owen Woodhouse, a Supreme Court judge, was established to report on accidental injury. This small and energetic commission produced in 18 months a radical, imaginative, well written, and exciting report. ${ }^{6}$ (Our Pearson Commission took five years.) The commission described the New Zealand system of 1967 as a: "Fragmented and capricious 
response to a social problem that cries out for co-ordinated and comprehensive treatment," and, the commission said, the system was "not good enough" and "needed to be changed." The commission was also bold in that it exceeded its remit: it was commonly understood that the inquiry was to be concerned only with accidents suffered by those who were employed, but the recommendations eventually made covered everybody in the community.

The report contained a spirited attack on the common law system. Too many injured people, it said, went uncompensated; the system was economically very inefficient; it was too slow; determining fault was unrealistically difficult; assessing lumpsum damages was speculative; and rehabilitation was hindered by the prolonged and adversarial system. Geoffrey Palmer ${ }^{3}$ has pointed out that the report's attack on the common law was "hardly balanced," and that the law does have some advantages -flexibility, sometimes satisfying a sense of justice, and very generously compensating some victims.

The Woodhouse Report went on to recommend a comprehensive State-run system of no-fault compensation for accidental injury. The report also emphasised, an emphasis that has since been somewhat forgotten, that: "Injury arising from accident needed an attack on three fronts"-safety, rehabilitation, and compensation, in that order of importance.

The Government produced a commentary on the report by October $1969,{ }^{7}$ and in that same month a select committee was established to "consider and report" on the original report. (All English-speaking people will be familiar with this system of "reporting on reports": it is democracy at work.) The select committee (the Gair Committee) reported in November 1970 and recommended the introduction of a watered-down version of the Woodhouse proposals. ${ }^{8}$ It suggested two schemes: one to cover all earners 24 hours a day, and one for all victims of motor accidents. A Bill along these lines was introduced into Parliament and received the royal assent in October 1972. In November 1972 the Labour party came to power in a general election, and in 1973 two accident compensation Acts were passed; the scheme was extended to cover all non-earners. The Accident Compensation Commission started with a skeleton staff almost immediately, and as from 1 April 1974 all accidents in New Zealand were covered by the Act. In its first year, as table I shows, the Commission received just over 100000 claims and declined only 784 .

TABLE I-Work and finances of the Accident Compensation Corporation since its start in 1974

\begin{tabular}{ccccc}
\hline $\begin{array}{c}\text { Year ending } \\
\text { 31 March }\end{array}$ & $\begin{array}{c}\text { Claims } \\
\text { received }\end{array}$ & $\begin{array}{c}\text { Claims } \\
\text { declined }\end{array}$ & $\begin{array}{c}\text { Total } \\
\text { income } \\
\text { (NZ\$m) }\end{array}$ & $\begin{array}{c}\text { Total } \\
\text { expenditure } \\
\text { (NZ\$m) }\end{array}$ \\
\hline 1975 & 105018 & 784 & $81 \cdot 316$ & 32.69 \\
1976 & 130657 & 2485 & 93.810 & $59 \cdot 25$ \\
1977 & 130235 & 3490 & 110.385 & 81.341 \\
1978 & 132438 & 5454 & 127.789 & 89.181 \\
1979 & 135369 & 4936 & 141.093 & 98.028 \\
1980 & 126391 & 3991 & 174.087 & 104.411 \\
1981 & 128787 & 2708 & 201.553 & 126.601 \\
& & & & \\
\hline
\end{tabular}

\section{How it works}

The Accident Compensation Corporation has three responsibilities: compensation for accidental injury; rehabilitation; and accident prevention. The last two can be dealt with quickly as until now the Accident Compensation Corporation has concerned itself mainly with compensation. This is human and understandable: just as medicine concerns itself primarily with managing acute problems rather than with preventing problems or engaging in long-term rehabilitation, so the Accident Compensation Corporation has done this until now.

The Accident Compensation Corporation has now, however, appointed liaison officers all over New Zealand, who are responsible for helping in the rehabilitation of individuals. Payments are made for adaptation of injured people's homes. Ison considered that rehabilitation programmes in New Zealand had improved since the advent of the Accident Compensation Corporation and that its programmes compared well with those in other countries. ${ }^{5} \mathrm{He}$ also thought, however, that those severely disabled were dealt with much better than those moderately disabled.

The Accident Compensation Corporation has a safety division, which has been expanded. It runs training courses for industry and others, inspects workplaces, gives advice, and produces publications. Again there is lots of room for expansion, and a need to work out with other government agencies who does what.

\section{Compensation}

The Accident Compensation Corporation operates three funds: the earners' fund; the motor vehicle fund; and the supplementary fund. The income for the earners' fund is raised by a levy on all employers and self-employed. The rate for employers varies according to the risk classification of the employment; the money is collected by the Inland Revenue. The money for the motor vehicle fund is collected by the Post Office as part of the motor vehicle licence fee. The supplementary fund comes from general government revenue. Benefits are paid to earners from the earners' fund unless the injury was caused in a car accident when the earner was not at work. Car accident victims are compensated from the motor vehicle fund unless the accident happened as part of the victim's work, and all other cases are charged to the supplementary fund.

The benefits are paid to those suffering "personal injury by accident," and the rub is to define what is an accident. The Accident Compensation Act does not attempt a definition but says:

"Personal injury by accident"

(a) Includes

(i) The physical and mental consequences of any such injury or of the accident;

(ii) Medical, surgical, dental, or first aid misadventure;

(iii) Incapacity resulting from an occupational disease or industrial deafness to the extent that cover extends in respect of the disease or industrial deafness ...;

(iv) Actual bodily harm including pregnancy and mental or nervous shock, suffered by any person by any act or omission of any other person (being an act or omission that occurs in New Zealand after the commencement of this section), and it is proved to the satisfaction of the Commission that the act or omission is within the description of any of the offences specified in ... the Crimes Act 1961 . . . irrespective of whether any person is charged with the offence;

(b) Except as provided in the last preceding paragraph, does not include

(i) Damage to the body or mind caused by a cardiovascular or cerebrovascular episode unless the episode is the result of effort, strain, or stress that is abnormal, excessive, or unusual for the person suffering it, and the effort, strain, or stress arises out of and in the course of the employment of that person as an employee;

(ii) Damage to the body or mind caused exclusively by disease, infection, or the aging process.

The intention is to exclude disability and death resulting from disease. This necessarily arbitrary distinction between accident and disease creates many difficulties, which will be discussed in the next article.

If the claimant can convince the Accident Compensation Corporation that he has been injured in an accident then he is entitled to a variety of benefits (table II). Earners after the first 
TABLE II-Benefits available under the Accident Compensation Act

Earnings-related compensation

Reasonable cost of medical or dental treatmen

Reasonable cost of transport to a doctor or hospital for initial treatment, or to home Reasonable cost of meals, accommodation, and transport to receive medical or rehabilitative treatment in certain cases

Reasonable cost of transport by ambulance

Compensation for damage to, or loss of, any clothing, spectacles, contact lens, or artificial limb or aid used or worn at the time of the accident

Payment for reasonable cost of necessary constant personal attention following injury Actual and reasonable expen

a result of the accident

Rehabilitation and retraining assistance

Lump sum for permanent physical disability

Lump sum for pain and suffering, disfigurement, and loss of enjoyment of life $\mathrm{mp}$ sum for dependent spouse (including de facto) and children (including children to whom the deceased stood in place of a parent) if death is a result of an

Compensation to a member of the household for losing services through injury or death by accident

spouse (including de facto) and other dependants may qualify for earnings-related compensation if death is a result of an accident

作 superannuation, pension, and the like, as a result of death by accident Compensation to anybody who can show actual and reasonable expenses or losses incurred in helping an accident victim

Reasonable funeral expenses

week (which is paid for by the employer unless the employee was injured by an accident at work) receive $80 \%$ of their preaccident income (up to a limit of about NZ $\$ 600$ a week-about $f^{250)}$ ) for as long as they are unable to work up to the age of 65 . If the person is killed these payments will be made to dependents. Lump sums are paid for two reasons: firstly, "permanent loss or impairment of any bodily function"; and, secondly, in "respect of the loss suffered by the person of amenities or capacity for enjoyment of life, including loss from disfigurement, and pain and mental suffering, including nervous shock and neurosis." As can be imagined, administering these lump-sum payments creates many problems, which will be considered in the next article.

\section{Appeal procedures}

A decision whether or not a person will be compensated and how much he will receive if he is entitled to a lump-sum payment is made by claims officers in the various regional offices of the Accident Compensation Corporation. If a claimant is unhappy with the decision then he can appeal to the Accident Compensation Corporation itself, which may internally grant the appeal or else a "hearing officer" will conduct an internal review of the decision. The next stage is to appeal to the Appeal Authority, which consists of a single judge. Then if leave is granted there can be an appeal to the Supreme Court, and, finally, on a point of law, to the Court of Appeal. In the year ending 31 March 1979 there were 4506 applications for review, and 2141 were heard before a hearing officer. The Appeal Authority had 207 appeals lodged, but very few ever go to the Supreme Court, and none has ever reached the Court of Appeal.

This is the first in a series of three articles.

\section{References}

${ }^{1}$ Royal Commission on Civil Liability and Compensation for Personal Injury. Report. London: HMSO, 1978. (Cmnd 7054.) (Pearson Commission.)

2 Anonymous. A neglected reform. The Times 1981 Aug 21:13 (col 1-3).

${ }^{3}$ Palmer G. Compensation for incapacity: a study of law and social change in New Zealand and Australia. Wellington: Oxford University Press, 1979.

4 Ison TG. Accident compensation. London: Croom Helm, 1980.

${ }^{5}$ Fahy JC. Accident compensation coverage. Wellington: ACC, 1980.

${ }^{6}$ Royal Commission of Inquiry. Compensation for personal injury in New Zealand. Wellington: New Zealand Government, 1967.

${ }^{7}$ Anonymous. Personal injury: a commentary on the report of the Royal Commission of Inquiry into Compensation for Personal Injury in New Zealand. Wellington: New Zealand Government, 1969.

8 Select Committee on Compensation for Personal Injury in New Zealand. Report. Wellington: New Zealand Government, 1970.
A patient says that he is allergic to alcohol; he develops wheezing after small amounts. Is this common, and what treatment is advised?

Some patients with asthma, and indeed rhinitis, complain that their symptoms are made worse when they drink alcoholic beverages. This is not uncommon, though I know of no well-documented series that give a true idea of the prevalence. Interestingly, it is often only specific wines, beers, or spirits that cause symptoms, which suggests that a particular component in the drink rather than alcohol causes the problem. Not all of those giving a history of attacks of asthma or rhinitis after drinking alcoholic beverages develop such attacks on deliberate provocation testing. Indeed, Breslin and co-workers ${ }^{1}$ studied 11 such patients with asthma, of whom only four showed objective evidence for the development of asthma with a greater than $15 \%$ fall in the forced expiratory volume in one second. The history in these patients showed that they developed symptoms after ingesting beverages ranging from Chateauneuf-du-Pape to light ale and Johnnie Walker Red Label. Definite asthmatic reactions were precipitated when the particular alcoholic beverage was passed directly into the stomach through a nasogastric tube, suggesting that it was not inhalation of the alcoholic vapours that caused the problem. Similarly, pure ethyl alcohol did not lead to asthmatic reactions developing. This confirms the clinical impression that it is the congeners in the beverage that lead to an asthmatic attack developing. Wines, spirits, and beers are complex solutions containing in some cases over 400 different compounds as well as appreciable amounts of histamine. Apart from the contents of the alcoholic beverage such drinks, as with many foods, contain high concentrations of sulphur dioxide. Indeed, in the United Kingdom, the Preservatives in Food Regulations of 1975 allow up to $450 \mathrm{ppm}$ of sulphur dioxide in wine, and this gas is a potent precipitator of asthmatic attacks. The underlying mechanism by which congeners or preservatives in alcoholic beverages cause asthma is not understood. There is no evidence to suggest the involvement of specific IgE antibodies, and indeed many of the patients who suffer from this problem are not atopic. The cure, of course, is easy, and beneficial not only to the patient's respiratory tract! If he must imbibe alcoholic beverages for pressing social reasons, then good results may be achieved by prior inhalation of sodium cromoglycate. The administration of this drug has been shown, at least experimentally in different provocation tests, to inhibit the development of asthma after drinking reasonable quantities of alcohol.-ROBERT J DAVIES, consultant physician, London.

1 Breslin ABX, Hendrick DJ, Pepys J. Effect of disodium cromoglycate on asthmatic reactions to alcoholic beverages. Clin Allergy 1973;3:71-82.

How can the drug methotrexate be used to treat psoriasis in general practice? What dose should be given?

Although methotrexate is useful for treating patients with extensive, intractable psoriasis, it should not be used in general practice. It is also prescribed for patients with erythrodermic psoriasis and with severe pustular psoriasis. Such patients are always in hospital before starting treatment because of their extensive, and at times life-threatening, psoriasis. Before treatment begins the dermatologist must check that the renal, marrow, and liver functions are satisfactory as the drug may cause acute necrosis of the liver, cirrhosis, and marrow depression. The general practitioner could help by monitoring the full blood count and liver function tests four days after each treatment, which is usually $10-20 \mathrm{mg}$ by mouth or parenterally every one to two weeks. Repeat liver biopsies are needed after cumulative doses of $1.5 \mathrm{~g}$. Most skin departments have a special clinic for such patients, but awareness by the general practitioner of the patient's needs and potential problems due to the drug is important. In particular, certain drugs will increase the toxicity of methotrexate, and thus the general practitioner should try to ensure that the patient does not take alcohol, phenylbutazone, or salicylates. Conception should not be allowed while taking the drug and for three months after stopping treatment.-W J CUNLIFFE, consultant dermatologist, Leeds.

Baker H, Dahl MCG. Drug reactions II. Methotrexate and the liver. $\mathrm{Br} F$ Dermatol Baker H. Psoriasis. Proceedings 2nd International Symposium. Farber EM, Cox AJ,
eds. New York. Yorke Medical Books, 1977 . 